\title{
PEMBERIAN ASI BERHUBUNGAN DENGAN DERAJAT STUNTING BAYI USIA 6-12 BULAN
}

\author{
Diyah Arini ${ }^{1}$, Christina Yuliastuti ${ }^{2}$, Essa Nevya Putri $^{3}$ \\ Program Studi Keperawatan, Stikes Hang Tuah Surabaya \\ Email koresponden diyaharini76@yahoo.co.id
}

\begin{abstract}
Background: Mother's Milk (ASI) is the most important food and drink for babies. Additional food besides breast milk at an earlier age can increase morbidity. The degree of stunting is defined as a measure of nutritional status based on height by age in the z-score that is categorized into mild stunting, moderate stunting and severe stunting. Objective: To analyze the relationship between breastfeeding and the degree of stunting in infants aged 6-12 months in the Work Area of the Kenjeran Health Center in Surabaya. Method: In this study using a Deskriprif Observasional analytic research design with a cross sectional approach. The research population of all stunting infants in the working area of the Surabaya Kenjeran Health Center was 325 infants in 4 Kelurahan including Kenjeran Kelurahan, Bulak Kelurahan, Kedung Cowek Kelurahan, and Sukolilo Kelurahan. The sample technique uses Probability Sampling by using Stratified Random Sampling as many as 97 babies. The research instrument used a questionnaire to determine breastfeeding. As well as measuring the degree of stunting using an observation sheet adjusted to the z-score table (body length / age). Results: The results showed that infants aged 6-12 months who experienced the worst degree of stunting consume milk partially. The Spearman rho test showed an association between breastfeeding and the degree of stunting $\rho=0,000(\rho<\alpha=$ 0.05). Conclusion: Breastfeeding is related to the degree of stunting, so that it can be socialized about the movement of the first 1000 days of life and counseling about providing complementary foods suitable for the age of the baby to cadres in the Work Area of the Kenjeran Health Center in Surabaya.
\end{abstract}

Keywords : Breastfeeding, Stunting Degrees, Infants 6-12 Months

Negara Indonesia memiliki masalah kesehatan yang beragam salah satunya adalah gizi pada anak. Masalah gizi yang paling banyak angka kejadian dan mendapatkan perhatian lebih adalah stunting. Menurut Hidayati, dkk (2010), dalam Mediana, (2016) menjelaskan bahwa Stunting merupakan gangguan pertumbuhan secara fisik yang mengakibatkan penurunan kecepatan pertumbuhan secara linear sehingga anak gagal mencapai tinggi badan yang optimal. Salah satu indikator yang dapat menunjukkannya adalah dengan nilai z-score tinggi badan menurut umur kurang dari -2 SD (1). Menurut PUSDATIN (2018) Capaian ASI pada tahun 2017 adalah 35,7 persen yang dapat dikatakan masih jauh dari standart capaian yakni 80 persen. Tidak berhasilnya ASI eksklusif berhubungan dengan kejadian stunting pada anak (Rahayu dkk, 2014)

Secara global, pada tahun 2010 prevalensi anak pendek sebesar 171 juta anakanak di mana 167 juta kejadian terjadi di negara berkembang (3). Prevalensi di Asia Tenggara sebesar 25,7 persen atau 14,9 juta anak mengalami stunting dengan nilai prevalensi dkatakan stunting bila lebih dari 20 persen WHO (2018). Hasil Riset Kesehatan Dasar tahun 2018 menunjukkan bahwa prevalensi kejadian stunting pada balita secara Nasional adalah 30,8 persen yang terdiri dari sangat pendek 11,5 persen dan pendek 19,3 persen yang berarti ada penurunan terhadap angka kejadian stunting dibandingkan tahun 2013 yakni dengan prevalensi 37,2 persen. Prevalensi yang didapat saat ini memang terdapat penurunan akan tetapi angka tersebut masih dikatakan cukup besar jika dibandingkan dengan nilai batasan kejadian stunting menurut Badan Kesehatan Dunia (WHO), yakni sebesar 20 persen. Data prevalensi balita stunting di Jawa Timur sebesar 25 persen Kemenkes (2018). Studi pendahuluan di Puskesmas Kenjeran Surabaya didapatkan bahwa data terakhir pada Agustus 2018 terdapat 279 balita mengalami stunting dari jumlah balita sebanyak 2767 balita dengan prevalensi sebesar 25,2 persen 
Stunting biasanya muncul pada 1000 hari kehidupan pertama akibat terjadinya asupan gizi yang kurang dan penyakit infeksi. Balita membutuhkan nutrisi yang cukup dalam kelangsungan kecepatan tumbuh kembangnya guna mencapai pertumbuhan yang optima Suthutvoravut (2015). Stunting pada balita perlu menjadi perhatian khusus karena dari proses penyakit tersebut banyak dampak yang akan didapatkan yakni perkembangan fisik dan mental anak yang terhambat (6). Balita yang mengalami stunting memiliki risiko terjadinya penurunan kemampuan intelektual, produktivitas dan peningkatan risiko penyakit degeneratif di masa mendatang (Prihutama, dkk. 2018)

Pada penelitian sebelumnya oleh Kartiningrum (2015) menyebutkan bahwa riwayat asi yang tidak eksklusif merupakan faktor risiko terjadinya gizi kurang pada balita. Asupan makanan yang tidak seimbang termasuk dalam pemberian ASI eksklusif yang tidak sesuai yang diakibatkan oleh keterbatasan makanan sehat yang bisa dikonsumsi (8). Dalam penelitian Walalangi (2019) terdapat hubungan yang bermakna antara status menyusui eksklusif dengan kejadian stunting. Dari hasil penelitian bahwa yang tidak mendapat ASI eksklusif lebih berisiko mengalami stunting (9). Balita/Baduta (Bayi dibawah usia Dua Tahun) yang mengalami stunting akan memiliki tingkat kecerdasan tidak maksimal, menjadikan anak lebih rentan terhadap penyakit dan di masa depan dapat beresiko pada menurunnya tingkat produktivitas. Pada akhirnya secara luas stunting akan menghambat pertumbuhan ekonomi, meningkatkan kemiskinan dan memperlebar ketimpangan (Pangalila YV, dkk, 2017).

Mencermati permasalahan stunting memiliki dampak yang sangat serius tak hanya bagi individu penderita tetapi juga bagi negara maka perlu dicari upaya pemecahan masalah tersebut. Salah satu penyebab stunting adalah akibat kurangnya zat gizi. Air Susu Ibu (ASI) diketahui mengandung berbagai zat gizi yang dibutuhkan dalam pertumbuhan. Menurut rekomendasi WHO (2018) menjelaskan bahwa air susu ibu yang diberikan secara eksklusif menjadi salah satu strategi tepat untuk mengurangi angka kejadian stunting. Namun studi mengenai hubungan pemberian ASI dengan kejadian stunting masih terbatas. Melihat kondisi tersebut peneliti tertarik untuk melakukan penelitian lebih lanjut tentang Hubungan Antara Pemberian ASI dengan Derajat Stunting Pada Bayi Usia 6-12 Bulan di Wilayah Kerja Puskesmas Kenjeran Surabaya.

\section{METODE}

Penelitian ini adalah penelitian Deskriprif Observasional Analitik dengan pendekatan cross sectional. Populasi penelitian bayi stunting di wilayah kerja Puskesmas Kenjeran Surabaya adalah 325 balita di 4 Kelurahan yang meliputi Kelurahan Kenjeran, Kelurahan Bulak, Kelurahan Kedung Cowek, dan Kelurahan Sukolilo. Teknik pengambilan sampel menggunakan Probability Sampling dengan Stratified Random Sampling sebanyak 97 bayi. Instrumen penelitian menggunakan kuesioner untuk menentukan pemberian ASI. Serta mengukur derajat stunting menggunakan lembar observasi yang disesuaikan dengan tabel z-score (panjang badan / umur). Instrument penelitian menggunakan kuisoner untuk mengetahui pemberian ASI. Serta mengukur derajat stunting menggunakan lembar observasi yang disesuaikan dengan tabel z-score (panjang badan/usia). Dalam penelitian ini penulis hanya ingin mengetahui apakah ada hubungan antara pemberian ASI dengan derajat stunting pada bayi usia 6-12 bulan di Wilayah Kerja Puskesmas Kenjeran Surabaya.

\section{HASIL}

Data umum hasil penelitian merupakan gambaran tentang karakteristik responden yang meliputi jenis kelamin bayi, pendididikan orangtua, pekerjaan orangtua, berat badan lahir bayi, ASI, Pemberian MP-ASI, imunisasi dan penghasilan keluarga. 
1. Karakteristik Respomden Berdasarkan Jenis Kelamin Bayi Usia 6-12 Bulan Stunting.

Tabel 1. Karakteristik Responden

\begin{tabular}{|c|c|c|}
\hline Jenis Kelamin & Frekuensi & Persentase (\%) \\
\hline Laki-laki & 41 & 42,3 \\
\hline Perempuan & 56 & 57.7 \\
\hline Total & 97 & 100.0 \\
\hline \multicolumn{3}{|l|}{ Pendidikan Ayah } \\
\hline SD Tidak Tamat & 1 & 1.0 \\
\hline SD Tamat & 9 & 9.3 \\
\hline SLTP Tidak Tamat & 16 & 16.5 \\
\hline SLTP Tamat & 35 & 36.1 \\
\hline SLTA Tidak Tamat & 16 & 16.5 \\
\hline SLTA Tamat & 14 & 14.4 \\
\hline $\begin{array}{l}\text { PT Tidak Tamat } \\
(\mathrm{D} 3, \mathrm{~S} 1, \mathrm{~S} 2)\end{array}$ & 2 & 2.1 \\
\hline PT Tamat (D3,S1,S2) & 4 & 4.1 \\
\hline Total & 97 & 100.0 \\
\hline \multicolumn{3}{|l|}{ Pendidikan Ibu } \\
\hline Tidak Sekolah & 5 & 5.2 \\
\hline SD Tidak Tamat & 1 & 1.0 \\
\hline SD Tamat & 26 & 26.8 \\
\hline SLTP Tidak Tamat & 4 & 4.1 \\
\hline SLTP Tamat & 36 & 37.1 \\
\hline SLTA Tidak Tamat & 7 & 7.2 \\
\hline SLTA Tamat & 15 & 15.5 \\
\hline $\begin{array}{l}\text { PT Tidak Tamat } \\
\text { (D3,S1.S2) }\end{array}$ & 2 & 2.1 \\
\hline PT Tamat (D3,S1,S2) & 1 & 1.0 \\
\hline Total & 97 & 100.0 \\
\hline \multicolumn{3}{|l|}{ Pekerjaan Ayah } \\
\hline PNS/TNI/POLRI & 5 & 5.2 \\
\hline Pedagang & 62 & 63.9 \\
\hline Petani Pemilik & 4 & 4.1 \\
\hline Jual Jasa (Penjahit,dll) & 26 & 26.8 \\
\hline Total & 97 & 100.0 \\
\hline \multicolumn{3}{|l|}{ Pekerjaan Ibu } \\
\hline Tidak Bekerja & 58 & 59.8 \\
\hline Pedagang & 23 & 23.7 \\
\hline Jual Jasa (Penjahit,dll) & 16 & 16.5 \\
\hline Total & 97 & 100.0 \\
\hline
\end{tabular}

Tabel 1 menunjukkan bahwa sebagian besar responden dalam penelitian ini adalah perempuan (ibu bayi) dengan tingkat pendidikan terbanyak baik ibu maupun kepala keluarga adalah tamat SMP, dalam hal pekerjaan responden kepala keluarga lebih banyak bekerja sebagai pedagang dan ibu lebih banyak sebagai ibu rumah tangga atau tidak bekerja.

2. Karakteristik Riwayat Berat Badan Lahir Bayi 
Tabel 2. Riwayat Berat Badan Lahir dan Status Menyusui

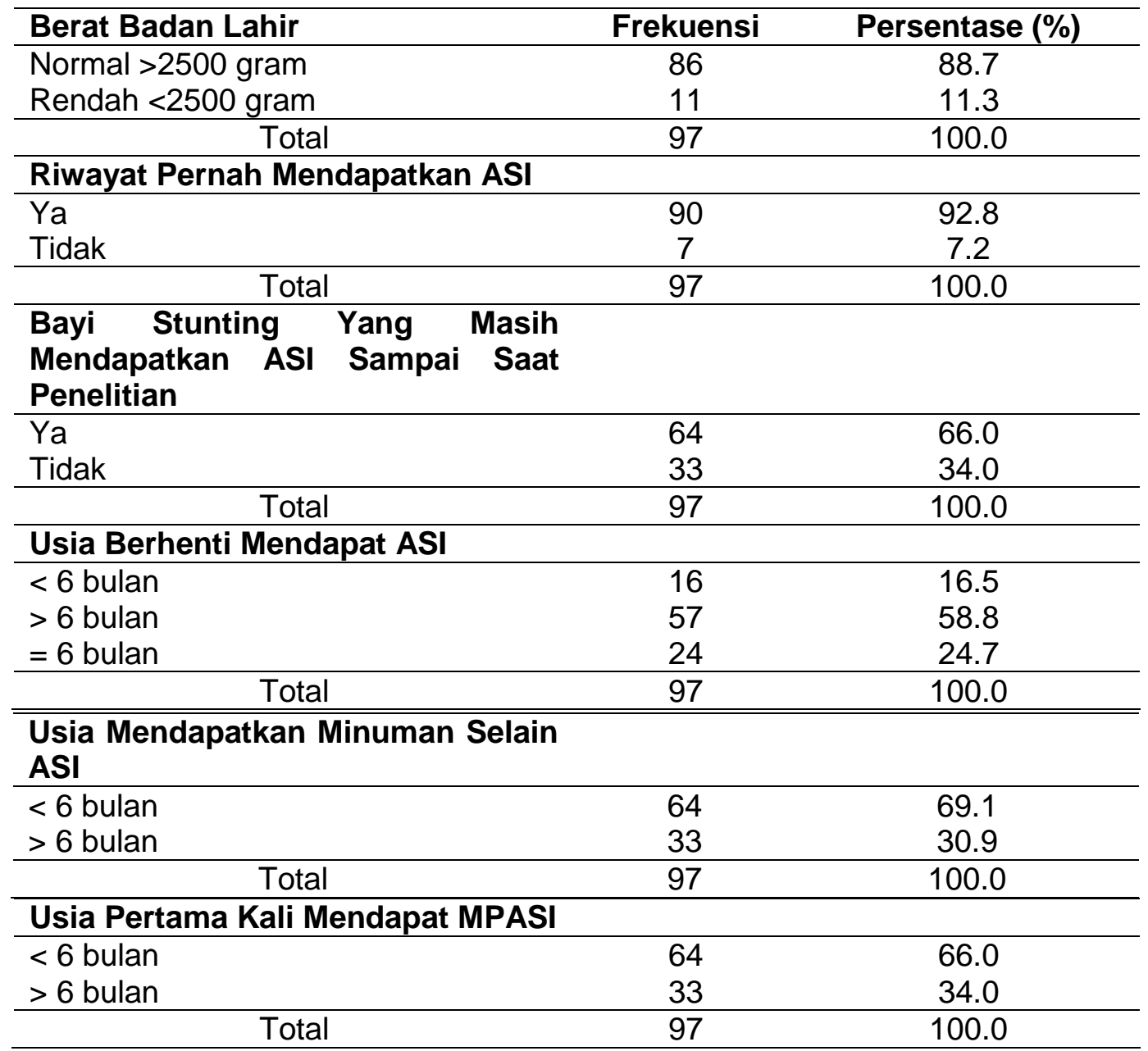

Tabel 2 menunjukkan bahwa berat badan lahir bayi dalam penelitian ini sebagian besar >2500 gram, dan mendapat ASI hingga penelitian ini dilakukan, dan berhenti menyusui diusia $>6$ bulan sedangkan bayi yang mendapat minuman/MPASI selain ASI lebih banyak diberikan sebelum usia 6 bulan

3. Jenis Makanan Yang Diberikan dan Derajad Stunting

Tabel 3. Jenis Makanan Yang Diberikan Pada Bayi Usia 6-12 Bulan di Wilayah Kerja Puskesmas Kenjeran Surabaya Mei 2019.

\begin{tabular}{lcc}
\hline \multicolumn{1}{c}{ Jenis Makanan } & Frekuensi & Persentase (\%) \\
\hline Bubur Nasi & 46 & 47.4 \\
Bubur Susu & 13 & 13.4 \\
Cerelaks & 8 & 8.2 \\
Biskuit & 9 & 9.3 \\
Susu Formula & 21 & 21.6 \\
\hline \multicolumn{1}{c}{ Total } & 97 & 100 \\
\hline Derajat Stunting & & \\
\hline Mild Stunting & 5 & 5.2 \\
Moderate Stunting & 26 & 26.8 \\
Severe Stunting & 66 & 68.0 \\
\hline \multicolumn{1}{c}{ Total } & 97 & 100.0 \\
\hline
\end{tabular}


Tabel 3 menunjukan Jenis Makanan Yang Diberikan Pada Bayi Usia 6-12 Bulan lebih banyak dalam bentuk bubur nasi dan dan sebagian besar bayi dalam penelitian ini dikategorikan sebagai severe stunting $968 \%$.

4. Hubungan Antara Pemberian ASI Dengan Derajat Stunting Pada Bayi Usia 6-12 Bulan di Wilayah Kerja Puskesmas Kenjeran Surabaya.

Tabel 4. Hubungan Antara Pemberian ASI Dengan Derajat Stunting Pada Bayi Usia 612 Bulan di Wilayah Kerja Puskesmas Kenjeran Surabaya.

\begin{tabular}{|c|c|c|c|c|c|c|c|c|}
\hline \multicolumn{9}{|c|}{ Derajat Stunting } \\
\hline \multirow{2}{*}{$\begin{array}{c}\text { Pemberian } \\
\text { ASI }\end{array}$} & \multicolumn{2}{|c|}{ Mild stunting } & \multicolumn{2}{|c|}{ ModerateStunting } & \multicolumn{2}{|c|}{ Severe Stunting } & \multicolumn{2}{|r|}{ Total } \\
\hline & $f$ & $\%$ & $f$ & $\%$ & $f$ & $\%$ & $\mathrm{~N}$ & $\%$ \\
\hline Non ASI & 0 & $0 \%$ & 1 & $1 \%$ & 6 & $6,81 \%$ & 7 & $7,81 \%$ \\
\hline Parsial & 0 & $0 \%$ & 0 & $0 \%$ & 60 & $61,8 \%$ & 60 & $61,8 \%$ \\
\hline Predominan & 0 & $0 \%$ & 25 & $25,77 \%$ & 0 & $0 \%$ & 25 & $25,77 \%$ \\
\hline Eksklusif & 5 & $5,15 \%$ & 0 & $0 \%$ & 0 & $0 \%$ & 5 & $5,15 \%$ \\
\hline Total & 5 & $5,15 \%$ & 26 & $26,77 \%$ & 66 & 68,61 & 97 & $100 \%$ \\
\hline & & i Uii sta & iks & rmen rho & 000 & $=0.05)$ & & \\
\hline
\end{tabular}

Hasil analisis Spearmen rho menunjukkan terdapat hubungan antara Pemberian ASI dengan derajat stunting pada bayi usia 6-12 bulan di Wilayah Kerja Puskesmas Kenjeran Surabaya $(p=0.001)$.

\section{PEMBAHASAN}

Penelitian ini dirancang untuk memberikan gambaran interpretasi dan mengungkap hubungan antara Pembeian ASI dengan Derajat Stunting Pada Bayi Usia 6-12 Bulan di Wilayah Kerja Puskesmas Kenjeran Surabaya. Sesui dengan tujuan penelitian, maka akan dibahas hal-hal berikut :

\section{Pemberian ASI}

Berdasarkan tabel 5.17 memperlihatkan bahwa sebagian besar bayi stunting usia 6-12 bulan di Wilayah Kerja Puskesmas Kenjeran Surabaya diberikan ASI secara parsial sebanyak 60 bayi (61.9\%), sebagian kecil diberikan ASI secara predominan sebanyak 25 bayi $(25,8 \%)$, sebagian kecil diberikan Non ASI sebanyak 7 bayi $(7,2 \%)$ dan sebagian kecil lainnya sebanyak 5 bayi $(5,2 \%)$ diberikan ASI secara eksklusif.

Bayi usia 6-12 bulan dengan sebagian besar pemberian ASI secara parsial di Wilayah Kerja Puskesmas Kenjeran Surabaya sebanyak 60 bayi $(61,9 \%)$. Berdasarkan data pemberian ASI dengan pendidikan ibu, pada ibu yang memberikan ASI parsial berbendidikan SLTP Tamat sebanyak 21 ibu $(21,64 \%)$, kemudian ibu yang memberikan ASI predominan sebagian kecil berpendidikan SLTP Tamat yakni 8 ibu (8,24\%). Sebagian kecil ibu yang memberikan ASI eksklusif sebanyak 4 ibu (4,12\%) juga berpendidikan SLTP Tamat dan sebagian kecil yakni 3 ibu (3,10\%) berbendidikan yang sama. Hasil wawancara dengan orang tua menyatakan bahwa riwayat orangtua sebagian besar berprofesi sebagai nelayan pencari ikan dengan penghasilan yang didapatkan cukup untuk memenuhi kebutuhan sehari-hari. Ekonomi keluarga memiliki peranan penting dalam menentukan tingkat pendidikan seseorang karena tanpa ekonomi yang memadai dunia pendidikan tidak akan berjalan dengan baik (Mukhlis, 2011). Semakin tinggi pendidikan ibu semakin berpengaruh terhadap praktik perawatan anak serta mampu menjaga dan merawat lingkungan dengan baik dibandingkan dengan pendidikan ibu yang rendah. Selain itu, tingkat pendidikan ibu turut menentukan mudah tidaknya seorang ibu dalam menyerap dan memahami pengetahuan gizi dan dapat menentukan tindakan selanjutnya saat menemui permasalahan gizi didalam keluarga 
Lailatul M (2015). Posisi sosial nelayan masih dianggap rendah karena keterasingan nelayan, sedikitnya waktu dan kesempatan nelayan untuk berinteraksi dengan masyarakat lainnya, hal ini disebabkan sebagian besar waktunya digunakan untuk menangkap ikan daripada bersosialisasi dengan masyarakat nonnelayan yang secara geografis relatif jauh dari pantai Satria A, dkk. (2015). Hal ini juga memungkinkan adanya hambatan terhadap akses informasi akan pentingnya pemberian ASI. Peneliti berasumsi bahwa masyarakat pesisir memiliki barier terhadap informasi-informasi yang dibutuhkan dalam pemeliharaan kesehatannya, khususnya kebutuhan gizi pada bayi.

\section{Derajat Stunting}

Berdasarkan tabel 4 memperlihatkan bahwa bayi stunting usia 6-12 bulan di Wilayah Kerja Puskesmas Kenjeran Surabaya sebagian besar bayi mengalami derajat severe stunting sebanyak 66 bayi $(68 \%)$, sebagian kecil 26 bayi $(26,8 \%)$ mengalami derajat moderate stunting sedangkan 5 bayi $(5,2 \%)$ mengalami mild stunting.

Bayi Stunting usia 6-12 bulan dengan derajat severe stunting sebanyak 66 bayi (68\%), berdasarkan data derajat stunting dan pendidikan ibu, pada ibu yang memberikan ASI parsial berpendidikan SLTP Tamat sebanyak 21 ibu $(21,64 \%)$, kemudian ibu yang memberikan ASI predominan sebagian kecil berpendidikan SLTP Tamat yakni 8 ibu $(8,24 \%)$. Sebagian kecil ibu yang memberikan ASI eksklusif sebanyak 4 ibu $(4,12 \%)$ juga berpendidikan SLTP Tamat dan sebagian kecil yakni 3 ibu (3,10\%) berbendidikan yang sama. Hasil wawancara dengan orangtua menyatakan bahwa riwayat orangtua sebagian besar berprofesi sebagai nelayan pencari ikan dengan penghasilan yang didapatkan cukup untuk memenuhi kebutuhan sehari-hari. Ekonomi keluarga memiliki peranan penting dalam menentukan tingkat pendidikan seseorang karena tanpa adanya ekonomi yang cukup maka dunia pendidikan tidak akan berjalan dengan baik Ikeda N (2013). Semakin tinggi pendidikan ibu semakin berpengaruh terhadap praktik perawatan anak serta mampu menjaga dan merawat lingkungan dengan baik dibandingkan dngan pendidikan ibu yang rendah. Selain itu, tingkat pendidikan ibu turut menentukan mudah tidaknya seorang ibu dalam menyerap dan memahami pengetahuan gizi dan dapat menentukan tindakan selanjutnya saat menemui permasalahan gizi didalam keluarga Nadhiroh(2015). Stunting secara signifikan dikaitkan dengan tingkat pendidikan ibu. Tingkat pendidikan ibu yang lebih tinggi mengurangi kemungkinan stunting dan kondisi underweight Makoka (2015). Peneliti berasumsi bahwa pendidikan ibu dan pengetahuan ibu mengenai kebutuhan nutrisi pada masa antenatal, serta pada saat merawat bayi dengan stunting sangatlah berkaitan, Perawatan bayi dengan stunting membutuhkan perhatian khusus supaya mendukung pertumbuhan dan perkembangan selanjutnya.

3. Hubungan Antara Pemberian ASI dengan Derajat Stunting Pada Bayi Usia 6-12 Bulan di Wilayah Kerja Puskesmas kenjeran Surabaya.

Berdasarkan hasil uji statistik Spearman rho nilai kemaknaan $\rho=0,000$ dengan taraf signifikan 0,01 $(\rho<0,05)$ dapat disimpulkan bahwa hasil tersebut menunjukkan terdapat hubungan antara pemberian ASI dengan derajat stunting pada bayi usia 6-12 bulan di Wilayah Kerja Puskesmas Kenjeran Surabaya. Ini sejalan dengan penelitian Harikedua (2019) bahwa Terdapat hubungan antara riwayat pemberian ASI Eksklusif dengan kejadian stunting dengan nilai $p$-value $<0,039$ (Harikedua V T, 2019).

Stunting yang dialami bayi diakibatkan oleh pemberian makanan selain ASI yang tidak sesuai dengan usianya (terlalu dini) menyebabkan terhambatnya perkembangan dalam pertumbuhan. Bayi yang mengalami stunting memiliki risiko terjadinya penurunan kemampuan intelektual, produktivitas dan peningkatan risiko penyakit degeneratif di masa mendatang (Prihutama NY, 2018).

Pada tabel 3 memperlihatkan bahwa hubungan antara pemberian ASI dengan derajat stunting pada bayi usia 6-12 bulan di Wilayah Kerja Puskesmas Kenjeran Surabaya dan didapatkan hasil bahwa dari 97 bayi responden yang dikategorikan 
Severe stunting dengan Pemberian ASI secara parsial sebagian besar sebanyak 60 bayi $(61,8 \%)$, kategori derajat moderate stunting dengan ASI secara predominan 25 bayi $(25,77 \%)$, dan kategori derajat mild stunting yang diberikan ASI eksklusif 5 (5,15\%). Berdasarkan hasil uji statistik Spearmen rho nilai kemaknaan $\rho=0,000$ dengan taraf signifikan $0,01(\rho<0,05)$ dapat disimpulkan bahwa hasil tersebut menunjukkan terdapat hubungan antara Pemberian ASI dengan derajat stunting pada bayi usia 6-12 bulan di Wilayah Kerja Puskesmas Kenjeran Surabaya. Hubungan antara pemberian ASI dengan derajat stunting pada bayi usia 6-12 bulan di Wilayah Kerja Puskesmas Kenjeran Surabaya dan didapatkan hasil bahwa dari 97 bayi responden yang dikategorikan Severe stunting dengan Pemberian ASI secara parsial sebagian besar sebanyak 60 bayi $(61,8 \%)$, Bayi yang mengalami severe stunting dikarenakan oleh pemberian ASI secara parsial. Pemberian ASI secara parsial ketika bayi masih disusui, pernah diberi makanan prelakteal selain makanan dan minuman berbasis air seperti susu formula,biscuit, bubur, nasi lembek, pisang atau makanan yang lain. Hasil ini didukung oleh penelitian penelitian Teshome yakni anak yang diberikan MP-ASI terlalu dini ( $<4$ bulan) beresiko menderita kejadian stunting. Pemberian MP-ASI pada usia dini yaitu pada usia 0 sampai 2 bulan dapat meningkatkan risiko stunting pada balita usia 2-4 tahun dan terlambatnya memberikan MP-ASI juga menyebabkan pertumbuhan dan perkembangan bayi menjadi terhambat karena kebutuhan gizi tidak tercukupi (Rambitan W, 2019).

Hubungan antara pemberian ASI dengan derajat stunting pada bayi usia 6-12 bulan di Wilayah Kerja Puskesmas Kenjeran Surabaya dan didapatkan hasil bahwa dari 97 bayi responden yang dikategorikan moderate stunting sebagian kecil dengan ASI secara predominan 25 bayi (25,77\%). Dikatakan menyusui predominan apabila bayi masih disusui, sejak lahir tidak pernah mendapatkan makanan dan minuman kecuali minuman berbasis air putih atau teh Arini D (2018). World Health Organization (WHO) merekomendasikan sebaiknya anak hanya disusui ASI selama paling sedikit enam bulan. Menyusui eksklusif adalah tidak memberi makanan atau minuman lain termasuk air putih kepada bayi Meilyasari F (2014). Bayi yang tidak diberi ASI eksklusif memiliki resiko sebanyak 6,54 kali lebih besar mengalami stunting dibandingkan dengan anak yang diberi ASI eksklusif (Suharni, 2010).

Hubungan antara pemberian ASI dengan derajat stunting pada bayi usia 6-12 bulan di Wilayah Kerja Puskesmas Kenjeran Surabaya dan didapatkan hasil bahwa dari 97 bayi responden yang dikategorikan severe stunting sebagian kecil dengan non ASI 7 bayi $(7,81 \%)$. Dikatakan non ASI apabila bayi tidak diberikan ASI. Pada penelitian sebelumnya oleh Kartiningrum (2015) menyebutkan bahwa riwayat asi yang tidak eksklusif merupakan faktor risiko terjadinya gizi kurang pada balita. Bayi yang tidak diberi ASI eksklusif memiliki resiko sebanyak 6,54 kali lebih besar mengalami stunting dibandingkan dengan anak yang diberi ASI eksklusif (Auliya S, 2018).

Hubungan antara pemberian ASI dengan derajat stunting pada bayi usia 6-12 bulan di Wilayah Kerja Puskesmas Kenjeran Surabaya dan didapatkan hasil bahwa dari 97 bayi responden yang dikategorikan mild stunting sebagian kecil dengan ASI Eksklusif bayi (5,2\%). Hal ini tidak sejalan dengan penelitian yang dilakukan Yogi Subadra (2018) bahwa terdapat hubungan antara pemberian ASI eksklusif dengan balita pendek di Kecamatan Jatinangor dengan OR sebesar 4,521. Dapat dikatakan anak yang pola menyusui ASI eksklusif lebih berpeluang menjadi pendek dibandingkan anak yang pola menyusui non ASI eksklusif.

Hasil penelitian ini sejalan dengan penelitian yang dilakukan Nadhiroh di Surabaya tahun 2015 dan Kuchenbecker di Malawi tahun 2015 yaitu anak yang pola menyusui non ASI eksklusif mempunyai peluang lebih tinggi menjadi pendek dibandingkan ASI eksklusif(14). Perbedaan ini mungkin disebabkan oleh faktor lain yaitu jumlah ASI yang diberikan dan asupan gizi ibu menyusui yang memengaruhi ASI 
eksklusif. Konsumsi ASI yang kurang akan menyebabkan ketidakseimbangan proses metabolisme di dalam tubuh. Pada bayi bila hal ini terjadi terus menerus akan terjadi gangguan pertumbuhan dan perkembangan pada bayi ${ }^{(21)}$. Hal tersebut didukung pada penelitian Nizkiniaz di Iran mengatakan bahwa asupan gizi ibu menyusui berhubungan dengan komposisi ASI. Selain itu juga terdapat faktor lain yang perlu dipertimbangkan yaitu riwayat infeksi berulang seperti diare, infeksi saluran pernafasan atas, dan infeksi lainnya memengaruhi pertumbuhan tinggi balita (Subandra Y, 2018).

Martorell et al. (1994) menjelaskan bahwa anak-anak yang terhambat biasanya tumbuh menjadi orang dewasa yang terhambat. Ada peluang untuk membuat beberapa defisit tinggi selama masa remaja karena anak-anak yang kerdil sering mengalami keterlambatan dalam pematangan kerangka, memperpanjang periode waktu total untuk pertumbuhan tinggi badan. Namun, potensi untuk secara substansial mengurangi defisit tinggi selama masa remaja terbatas karena penundaan kematangan biasanya lebih pendek dari 2 tahun. Selain itu, remaja yang memasuki periode ini terhambat sering hidup di bawah kondisi gizi, sosial-ekonomi dan lingkungan yang sama yang memicu stunting ketika mereka masih anak-anak Dewey KG (2011). Stunting dapat memiliki efek jangka panjang pada perkembangan kognitif, prestasi sekolah, produktivitas ekonomi di masa dewasa dan hasil reproduksi ibu. Peneliti berasumsi bahwa penanganan stunting, khususnya pencegahan stunting adalah prioritas tinggi untuk mengurangi beban penyakit global dan untuk mendorong perkembangan ekonomi, sehingga berdasarkan hasil penelitian ini pemberian ASI berhubungan dengan derajat stunting maka diperlukan edukasi yang baik kepada masyarakat khususnya wilayah pesisir.

\section{KESIMPULAN}

Bayi Usia 6-12 Bulan di Wilayah Kerja Puskesmas Kenjeran Surabaya sebagian besar mengalami derajat severe stunting. Pemberian ASI memiliki hubungan signifikan dengan derajat stunting pada bayi usia 6-12 bulan di Wilayah Kerja Puskesmas Kenjeran Surabaya.

\section{DAFTAR PUSTAKA}

Arini D. Hubungan Antara Pola Pemberian ASI dengan Frekuensi Kejadian Diare dan ISPA Pada anak 6-12 Bulan di Wilayah Puskesmas Balongpanggang Gresik. 2016.

Auliya S. Hubungan Antara Derajat Stunting Dengan Gangguan Perkembangan Motorik Halus Anak Toddler di Wilayah Pesisir Surabaya. 信阳师范学院. 2018;10(2):1-15.

Dewey KG, Begum K. Long-term consequences of stunting in early life. Matern Child Nutr [Internet]. 2011 Oct [cited 2020 Apr 2];7(SUPPL. 3):5-18. Available

Harikedua VT, Tomastola YA, Ranti IN, Kamboa A. Riwayat Pemberian ASI Eksklusif, MP-ASI dengan Kejadian Stunting Pada Anak Usia 24-60 Bulan di Puskesmas Sangkub Kabupaten Boolang Mongondow Utara. GIZIDO. 2019;11(2):96-104.

Ikeda N, Irie Y, Shibuya K. Determinants of reduced child stunting in Cambodia: analysis of pooled data from three Demographic and Health Surveys. Bull World Health Organ. 2013 May;91(5):341-9.

KEMENKES. Riset Kesehatan Dasar (RISKESDAS) 2018. 2018.

Lailatul M, Ni'mah. C. Hubungan Tingkat Pendidikan, Tingkat Pengetahuan dan Pola Asuh Ibu dengan Wasting dan Stunting pada Balita Keluarga Miskin. Media Gizi Indones. 2015;10(2015):84-90.

LPPM Stikes Hang Tuah Pekanbaru. Permasalahan Anak Pendek ( Stunting ) dan 
Intervensi untuk Mencegah Terjadinya Stunting ( Suatu Kajian Kepustakaan Stunting Problems and Interventions to Prevent Stunting ( A Literature Review ). J Kesehat Komunitas. 2015;2(5).

Makoka D, Masibo PK. Is there a threshold level of maternal education sufficient to reduce child undernutrition? Evidence from Malawi, Tanzania and Zimbabwe. BMC Pediatr [Internet]. 2015 Aug 22 [cited 2020 Apr 2];15(1):96. Available from: http://bmcpediatr.biomedcentral.com/articles/10.1186/s12887-015-0406-8

Martorell et.al. Weight Gain in the First Two Years of Life Is an Important Predictor of Schooling Outcomes in Pooled Analyses from Five Birth Cohorts from Low and Middle-Income Countries. J Nutr. 2010;

Meilyasari F, Isnawati M. Faktor Resiko Kejadian Stunting Pada Balita Usia 12 Bulan di Desa Purwokerto Kecamatan Patebon,Kabupaten Kendal. 2014;

Nadhiroh, Siti Rahayu; Ni'mah K. Faktor yang berhubungan dengan kejadian Stunting pada Balita. Media Gizi Indones. 2015;1:13-9.

Prihutama NY, Rahmadi FA, Hardaningsih G. Pemberian Makanan Pendamping Asi Dini Sebagai Faktor Risiko Kejadian Stunting Pada Anak Usia 2-3 Tahun. J Kedokt Diponegoro. 2018;7(2):1419-30.

Pangalila YV, Punuh MI, Kapantow NH. Hubungan Antara Riwayat Pemberian ASI Eksklusif dengan Stunting Pada Anak Usia 6-24 Bulan di Wilayah Kerja Puskesmas Koya Kabupaten Minahasa. J Kesehat. 2017;1-7.

Rahayu A, Khairiyati L. Risiko Pendidikan Ibu Terhadap Kejadian Stunting Pada Anak 6-23 Bulan. Penel Gizi Makan. 2014;37(Ci):129-36.

Rahayuh A, Yulidasari F, Putri AO, Rahman F, Rosadi D. Faktor Resiko Yang Berhubungan Dengan Kejadian Pendek Pada Aanak Usia 6-24 Bulan. 2016;11(2).

Rambitan W, Purba RB, Kapantow NH. Hubungan Antara Riwayat Pemberian ASI Eksklusif dengan Kejadian Stunting pada Anak Batita di Wilayah Kerja Puskesmas Kawangkoan Kabupaten Minahasa. 2019;2010:8.

Satria A. Pengantar Sosiologi Masyarakat Pesisir [Internet]. Jakarta: Yayasan Pustaka Obor Indonesia; 2015 [cited 2020 Mar 28]. Available from: https://books.google.co.id/books?hl=en\&lr=\&id=WCNLDAAAQBAJ\&oi=fnd\&pg=PA $1 \& d q=$ karakteristik+masyarakat+pesisir\&ots=lcAtCT5z56\&sig=q3olsn_OSIsJuKGk

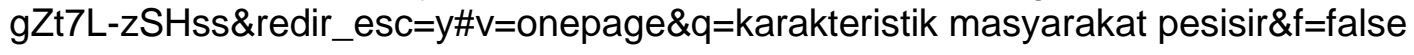

Subandra Y, Zuhairini Y, Djais J. Hubungan pemberian ASI Eksklusif dan Makanan Pendamping ASI terhadap Balita Pendek Usia 2 sampai 5 tahun di Kecamatan Jatinangor. J Sist Kesehat. 2018;3(3):142-8.

Suthutvoravut U, Abiodun PO, Chomtho S, Cruchet S. Composition of Follow-Up Formula for Young Children Aged 12 - 36 Months: Recommendations of an International Expert Group Coordinated by the Nutrition Association of Thailand and the Early Nutrition Academy. Nutr Metab. 2015;10:119-32.

Walalangi RG., Sahelangi O, Purba RB, Sentika N. Menyusui Eksklusif, Penyakit Diare Dengan Kejadian Stunting Pada Anak Balita Usia 24-59 Bulan di Wilayah Kerja Puskesmas Sangkub. GIZIDO. 2019;11(1):42-50.

Wiyogowati C. Kejadian stunting pada anak berumur dibawah lima tahun tahun (0-59 bulan) di provinsi papua barat tahun 2010 (analisis data riskesdas 2010) skripsi. 2012;2010:1-101.

WHO, UNICEF \& Group WB. Levels and Trends in Child Malnuutrition. 2018. 